\title{
Utilization of maternal health care services in the department of Matagalpa, Nicaragua
}

\author{
Lindsey Ann Lubbock ${ }^{1}$ and Rob B. Stephenson ${ }^{1}$
}

Suggested citation Lubbock LA, Stephenson RB. Utilization of maternal health care services in the department of Matagalpa, Nicaragua. Rev Panam Salud Publica. 2008;24(2):75-84.

\begin{abstract}
Objectives. To better understand the individual and community factors and perceptions that influence women's health care-seeking behaviors during pregnancy in order to increase women's utilization of maternal health services.

Methods. This study investigates the logistical and sociocultural barriers influencing women's utilization of maternal health services through 37 semi-structured in-depth interviews with women from the department of Matagalpa, Nicaragua.

Results. Results reveal that delays in seeking health care during pregnancy are influenced not only by poor access to care and economic barriers but also by individual and community knowledge and acceptance of maternal health services. Partner support, previous maternal health care experiences, and the degree of communication with other women and health workers affect women's decisions to seek care.

Conclusions. Evidence suggests that in order to improve maternal health outcomes in this region, interventions must be targeted at a hierarchy of levels: individual, household, and community.
\end{abstract}

Key words Maternal mortality, maternal health services, Nicaragua.

The United Nations estimates that 529000 women die each year from complications during pregnancy and childbirth (1) and approximately 22000 maternal deaths occur annually in the Latin America and Caribbean region (2). In Nicaragua, the second poorest country in Latin America and the Caribbean, the maternal mortality ratio has reached as high as 230 maternal deaths per 100000 live births in recent years (1). Common factors con-

\footnotetext{
Rollins School of Public Health, Emory University, Hubert Department of Global Health, Atlanta, Georgia, United States of America. Send correspondence and reprint requests to: Lindsey Ann Lubbock, e-mail: llubbock@hotmail.com
}

tributing to maternal mortality in Nicaragua include lack of access to services, high fertility, domestic violence, complications of unsafe abortions, a large young reproductive age population, and hypertension (3-5).

In recent decades, many strategies have been implemented in an attempt to improve maternal health outcomes around the world. Programs aimed at reducing the three delays in seeking care $^{2}$ include: improving primary pre-

\footnotetext{
As outlined by Thaddeus and Maine (6), the three delays in receiving appropriate health care include: the delay in the decision to seek care, the delay in arriving at a health facility, and the delay in the provision of adequate care at the facility.
}

vention through education and services; developing secondary prevention through early detection and treatment of conditions; and advancing tertiary prevention through treatment of conditions to reduce case fatality (7). While many strategies have attempted to address some of the economic, social, and physical factors and barriers contributing to poor maternal health outcomes, women's utilization of maternal health services is often influenced by perceived sociocultural, economic, and health system factors operating at the community, household, and individual level as well as within the larger social and political environments (8-11). Addressing 
health system factors and socioeconomic barriers is imperative for increasing women's overall utilization of health services. Reducing maternal mortality through increased service utilization, in turn, requires more effective public health interventions built on a clear understanding of women's perceptions of maternal care services within their cultural context. Although previous studies have examined factors contributing to poor maternal health outcomes and access to care in some regions in Nicaragua, a gap persists in understanding women's perceptions of barriers limiting their utilization of maternal health services in the department of Matagalpa. This study examines the complex interaction of socioeconomic and cultural factors influencing women's utilization of maternal health services in the department of Matagalpa, Nicaragua.

Nicaragua has experienced some success in reducing maternal mortality, but maternal deaths remain high in some regions. A recent Nicaraguan Ministry of Health report states that overall maternal mortality has dropped by $46 \%$ over the past 15 years. It should be noted, however, that over the past decade the mortality rate has only dropped by $22 \%$ (4). Maternal mortality ratios in Nicaragua range from 71.8 maternal deaths per 100000 live births (12) to 121 (13) and $230(1,14)$. In the department of Matagalpa, approximately $19 \%$ of women surveyed did not receive any prenatal care during their pregnancy for their most recent child born, and $31.2 \%$ of those who had received prenatal care attended less than four prenatal visits (15). While nearly $63 \%$ of children in the department of Matagalpa were delivered in a health facility in the five years prior to the 2001 survey, 37\% of deliveries still occurred in the home (15). In a county with a very young population, one in three women that die of maternal causes in the department of Matagalpa is an adolescent under 20 years of age (4).

In an attempt to improve maternal health, increase safe deliveries, and reduce infant and maternal mortality and morbidity, the Nicaraguan Ministry of Health has implemented the Women's Comprehensive Care (Atención Integral a La Mujer) program (4). Specific program interventions include emphasizing prenatal attention, clean and safe deliveries, family planning, and essential obstetric care (4). While this program encourages women's utilization of maternal health services, women continue to face many social, economic, and health system barriers when deciding whether or not to seek antenatal and delivery care (9-11, 16-19). Studies have examined women's individual perceptions influencing their utilization of prenatal care and delivery services in a wide range of socioeconomic and cultural contexts around the world $(9,11,16-20)$. While a woman's perceived value of care often influences her decision to seek care, the value she places on receiving prenatal care may differ from the value she ascribes to delivery care (21). Perceptions of quality of care-including promptness of care, competence of health workers, desire for privacy, perceived availability of equipment, disempowerment, abusive behavior, and friendliness of staff-often influence women's decisions to seek maternal health care $(9,11,22,23)$. Women's fear of doctors, medical examinations, and health procedures such as cesarean sections may influence their decision to seek care and the type of provider they use $(16,17,24)$. Religion, spirituality, and traditional beliefs have also contributed to women's perceptions and utilization of prenatal and delivery care services (24-27). In addition, while a woman's knowledge regarding pregnancy and delivery risks is an important factor contributing to her decision to seek care (6), it may not change her reproductive health behaviors due to conflicting priorities (16). For example, despite a high level of awareness of the potential risks, a woman may choose to use traditional methods rather than take advantage of institutional maternal services due to the influence of cultural mores. In Latin America, women take advantage of the knowledge of extended family members, who often assume responsibility for the family's well-being and encourage specific health decisions and behaviors (28).

Women's low status in society relative to the status of men contributes to maternal mortality (29). The role of men or partners in the decision-making process regarding women's prenatal and delivery care has been noted as a factor influencing women's health care-seeking behaviors $(9,16,24,30)$. Women's husbands' or mothers-inlaw's belief that maternal services are inappropriate or irrelevant has been shown to influence women's perceptions and utilization of care (31).

This qualitative research study aims to explore the perceptions and factors that influence women's decisions to seek maternal health care in rural and semirural municipalities within the department of Matagalpa, Nicaragua. ${ }^{3}$ Examining how delays in seeking and receiving care are augmented by individual and community attitudes and perceptions toward maternal health care is necessary to improve the health of pregnant women in this region and to provide the information needed for more effective targeting of public health interventions aimed at reducing maternal mortality.

\section{MATERIALS AND METHODS}

The department of Matagalpa is situated in north-central Nicaragua, which is located $120 \mathrm{~km}$ from the capital city of Managua. Approximately 31\% of Nicaragua's population (383 776) resides in this region, with $68 \%$ of the population living in rural areas (15). According to representatives from CARE Nicaragua, the department of Matagalpa has one regional hospital; 14 health centers (two of which have beds); and 126 health clinics (Erasmo

\footnotetext{
3 For the purpose of the study, the municipality of Waslala, which is politically assigned to the department of RAAN (Región Autónoma del Atlántico Norte), was included in the department of Matagalpa. According to CARE Nicaragua representatives, Waslala, due to its geographic accessibility receives health, education, and additional social service programs through the department of Matagalpa (Erasmo Jarquín, PhLic, and Daisy Navarro, MD, CARE Matagalpa, personal communication 29 January 2007)
} 
Jarquín, PhLic, and Daisy Navarro, MD, CARE Matagalpa, personal communication, 29 January, 2007).

Women in Nicaragua live in a society where machismo and conservative religious ideology prevail (32). Such ideology has limited women's reproductive health choices and empowered men to make the decisions regarding sex and reproductive health ${ }^{4}$ (33). Reproductive health indicators for the department of Matagalpa are more worrisome than the average indicators for the country overall (15). In this region, approximately $19 \%$ of women do not receive any prenatal care, and only $63 \%$ of births are delivered in a health facility (15). The total fertility rate in the region is 3.5 , compared to the national fertility rate of 3.2 (15). This qualitative investigation of women's maternal health careseeking behaviors and perceptions was conducted at rural and semirural health posts and health centers located in communities within the three municipalities of Matagalpa, La Dalia, and Waslala.

Qualitative data for this study was collected using an analytic induction approach. In-depth interviews with mothers 18 years of age or older were conducted between June and August 2006. Potential interview subjects were recruited using non-random snowball sampling of women waiting to receive health services at seven health clinics or centers in the three municipalities. Sample selection criteria included nonpregnant women, women who had at least one child under the age of 3 , and non-health workers (i.e. those who were not traditional birth attendants, health brigadistas [community health volunteers], nurses, or physicians). Referrals from community health volunteers were used to reach mothers who lived near the health posts. All of the women who volunteered to participate received an explanation of the pur-

\footnotetext{
4 Mann E. Familialism in Nicaragua: reproductive and sexual policy regimes, 1979-2002. Paper prepared for the International Sociological Association's Research Committee on Poverty, Social Welfare and Social Policy (RC19) Annual Conference. September 8-10, Northwestern University, Chicago, 2005. Available from: http://www.north western.edu/rc19/Mann.pdf.
}

poses of the study and provided verbal informed consent.

The interviews were conducted in Spanish using a pre-designed interview guide pretested for cultural appropriateness and clarity. The interview guide consisted of 31 multifaceted open-ended questions covering a range of issues related to maternal mortality, prenatal care activities, community and familial support, knowledge of pregnancy danger signs, and access to care. The interview guide included specific questions regarding the mother's maternal health care and delivery care experiences (e.g., "Where did you give birth to your child, and who was present during the birth?", and "Who accompanied you to the birth?") and broader questions related to community and individual beliefs about maternal health (e.g., "Does a method exist in your community for transporting a woman who has a pregnancy or birth emergency?", "Is it important to seek care during pregnancy?", and "Do others in your community think it is important to seek care during pregnancy?"). The interviewer used probing and question-rephrasing techniques to clarify questions and obtain details from the mothers. Participants were not required to answer all of the questions. Interviews were taperecorded, and field notes served as a backup method of retrieving data. Interviews were conducted until a saturation point was reached when no new information or insight into women's health-seeking behaviors and perceptions was obtained. In total, 37 interviews with mothers were conducted.

Interview field notes were written in Spanish by the researcher throughout the tape-recorded interviews. Preliminary analysis was conducted throughout the data collection process, allowing for early recognition of themes. All interviews were transcribed into Spanish and subsequently analyzed thematically using MAX Qualitative Data Analysis 2 (MAXqda2) (VERBI Software, Berlin, Germany, 2004). Each interview was coded using unique thematic in-vivo codes systematically applied throughout the text. The con- ceptual codes that evolved from the text and were used in this analysis were related to barriers to accessing care, gender roles, perceptions of health care, support, and the health care system.

\section{RESULTS}

\section{Use of prenatal care and delivery services}

Table 1 presents the patterns of maternal health care use among the women interviewed. The self-reported age of participants ranged from 18-40, with a mean age of 26 years. The mean number of children per woman interviewed was 3.3. ${ }^{5}$ The overwhelming majority of women interviewed (31 out of 37 , or $84 \%$ ) reported seeking prenatal care at health facilities. The mean total number of prenatal care visits among participants was 5 . While 31 women reported accessing prenatal care services, only $19(61 \%)$ of those women delivered in health facilities. All 10 of the women who stayed in a casa materna (maternity house) delivered in a hospital or health center. All five of the women who reported having a parity of one reported delivering in a health facility. However, only six $(67 \%)$ of the nine biparous women reported delivering their second child in a health facility. Only five (33\%) of the 15 women who reported a birth order of three or greater delivered in a health facility. All of the six women who did not attend any prenatal visits delivered at home.

\section{Logistical barriers to seeking care}

While the services are theoretically free, indirect costs such as financing travel to and from the clinic, leaving work to seek care, and paying for prescribed medicines were reported as considerable barriers to accessing care and treatment. Women also cited their need to prioritize spending money on

\footnotetext{
5 Mean calculated from 29 of the 37 respondents who reported their total number of children.
} 
TABLE 1. Antenatal care utilization and place of delivery (department of Matagalpa, Nicaragua, 2006)

\begin{tabular}{|c|c|c|c|c|c|c|}
\hline $\begin{array}{l}\text { Location } \\
\text { of interview }\end{array}$ & $\begin{array}{l}\text { Age of } \\
\text { mother }\end{array}$ & $\begin{array}{c}\text { Number } \\
\text { of } \\
\text { children }\end{array}$ & $\begin{array}{c}\text { Received } \\
\text { prenatal } \\
\text { care at } \\
\text { facility }\end{array}$ & $\begin{array}{l}\text { Reported } \\
\text { number } \\
\text { of } \\
\text { visits }\end{array}$ & $\begin{array}{l}\text { Use of } \\
\text { casa } \\
\text { materna }\end{array}$ & $\begin{array}{c}\text { Place of } \\
\text { last delivery }\end{array}$ \\
\hline La Dalia & 18 & 1 & Yes & 4 & Yes & Health facility \\
\hline La Dalia & 18 & 1 & Yes & 4 & Yes & Health facility \\
\hline La Dalia & 19 & 1 & Yes & 9 & No & Health facility \\
\hline La Dalia & 19 & 1 & Yes & 9 & Yes & Health facility \\
\hline La Dalia & 21 & $\ldots{ }^{a}$ & Yes & 9 & No & Home \\
\hline La Dalia & 22 & 2 & Yes & 3 & No & Home \\
\hline La Dalia & 22 & $\ldots{ }^{a}$ & Yes & 4 & No & Home \\
\hline La Dalia & 23 & 2 & Yes & 6 & No & Health facility \\
\hline La Dalia & 26 & $1+^{b}$ & No & 0 & No & Home \\
\hline La Dalia & 26 & $\ldots{ }^{a}$ & Yes & 4 & No & Health facility \\
\hline La Dalia & 28 & $\ldots{ }^{a}$ & Yes & 4 & No & Health facility \\
\hline La Dalia & 29 & 2 & Yes & 8 & No & Health facility \\
\hline La Dalia & 29 & 4 & Yes & 4 & No & Health facility \\
\hline La Dalia & 30 & 5 & No & 0 & No & Home \\
\hline La Dalia & 30 & 3 & Yes & 9 & Yes & Health facility \\
\hline La Dalia & 32 & 3 & Yes & 6 & No & Health facility \\
\hline La Dalia & 34 & 7 & No & 0 & No & Home \\
\hline La Dalia & 40 & 7 & Yes & 2 & No & Home \\
\hline Matagalpa & 19 & 2 & Yes & 4 & Yes & Health facility \\
\hline Matagalpa & 20 & 1 & Yes & 9 & No & Health facility \\
\hline Matagalpa & 24 & $\ldots{ }^{a}$ & Yes & 9 & No & Home \\
\hline Matagalpa & 25 & 2 & Yes & 4 & Yes & Health facility \\
\hline Matagalpa & 27 &.$^{a}$ & Yes & 4 & No & Home \\
\hline Matagalpa & 28 & 6 & Yes & 7 & No & Home \\
\hline Matagalpa & 29 & 2 & Yes & 5 & Yes & Health facility \\
\hline Waslala & 20 & 3 & Yes & 2 & No & Home \\
\hline Waslala & 21 & 2 & Yes & 4 & Yes & Health facility \\
\hline Waslala & 22 & 3 & No & 0 & No & Home \\
\hline Waslala & 22 & 6 & Yes & 9 & No & Home \\
\hline Waslala & 23 & 3 & No & 0 & No & Home \\
\hline Waslala & 23 & 2 & Yes & 4 & No & Home \\
\hline Waslala & 23 & 2 & Yes & 9 & No & Home \\
\hline Waslala & 25 & 3 & Yes & 4 & Yes & Health facility \\
\hline Waslala & 28 & 4 & No & 0 & No & Home \\
\hline Waslala & 35 & 8 & Yes & 4 & No & Home \\
\hline Waslala & 36 & 7 & Yes & 5 & No & Health facility \\
\hline Waslala & 39 & $1 t^{b}$ & Yes & 9 & Yes & Health facility \\
\hline
\end{tabular}

a Number of children was not obtained in these interviews.

${ }^{b}$ Women reported having more than one child but did not specify an exact number of children.

food and school-related expenditures for children and other family members as an economic barrier to service utilization. Women's perceptions of the cost of delivery care services, including the cost of using a partera (traditional birth attendant) and staying at the casa materna, contributed to their decisions to seek delivery care.

"Yes, it is the most difficult-the money-because I was alone. I did not have anyone to lend it to me." 26-year-old mother, La Dalia
"It was difficult because... sometimes you save the [money] but with other older children in classes [you must borrow money for school fees], and after [paying for the maternal services], you have to save to return this money." 32-year-old mother, La Dalia

"They told me that I would [have to] pay and afterward they told me that I did not have to pay [and] that it would be relaxing there [at the casa materna]. Then I said, 'No, it is better if I go home.' " 28-year-old mother, Matagalpa
Women's intentions to utilize prenatal and delivery care were often impeded by their inability to cover the cost of transportation, especially in an emergency. Emergency transportation options cited by women included: paying a neighbor with a car; paying for gas for the community ambulance; and calling on community members or the emergency transportation brigade (which often resulted in transport by hammock to the nearest health facility or to an available vehicle). The burden of accessing transportation was magni- 
fied by the challenge of traveling long distances alone along inadequate roads and/or in poor weather conditions.

\footnotetext{
"If someone does not have money or means [of transportation], she has to die in the home because here there is no one that will give it to you. We have to carry you or take you if there is a vehicle." 28-year-old mother, Waslala
}

"There is an ambulance here but there is no gas, and if you do not have [money] for gas you have to hold out here or die... those who don't have 200 córdobas can not be transported. [Women must] look for how to borrow [money]." 32-year-old mother, La Dalia

"When it is wintertime the roads become bad. . . and so some [women] do not go. Also, the centers are [often] closed and sometimes women can not [find] someone to accompany [them] on the roads ... and bad people [are on the roads], and for this sometimes [women] do not go. Sometimes the buses are dangerous." 25-year-old mother, Matagalpa

Familial support allowed women to overcome logistical barriers associated with seeking care. A woman's use of services was facilitated by her husband's financial contribution and recognition of the importance of maternal health care. Women frequently mentioned how husbands participated in securing monetary resources in preparation for the costs associated with transportation and care. Informed and engaged husbands indirectly supported women's utilization of services by bearing the burden of caring for their homes and children while women were seeking care. Financial preparation and support at the familial level permitted women, especially those experiencing a first- or second-order birth, to access delivery services, including staying at the casa materna to ensure the availability of emergency transportation.

"Saving. [Selling] animals, staple foods, corn, beans to always have money for the moment when you go to the hospital." 29-year-old mother, Matagalpa
"I was working but during the nine months of pregnancy I did not continue working ... my husband was working far away so he sent me the money." 22-yearold mother, La Dalia

"As always my mother accompanies me because I am always not well. I leave... my husband [with the house] and the kids and he cares for them." 28-year-old mother, La Dalia

\section{Value of health care}

Women's knowledge and acceptance of the importance of maternal health care and healthy pregnancy practices are shaped by previous experiences as well as formal and informal communication within the community and households. Many women who utilized maternal health services believed it was important as a means of reducing the risks of complications and ensuring the health of the unborn child. Women-often those who delivered healthy babies-praised the quality of care and attention they received during pregnancy and delivery, noting the importance of receiving vitamins, vaccinations, and examinations during pregnancy and the benefits of such care in regard to the healthy delivery of the new baby.

"In the health center they give you vitamins. They check you to see if the baby is well, how it is coming along. For this reason I go to the health center-to see how I am and the baby." 23-year-old mother, Waslala

"More than anything they always cared for me in the place that they sent me for the birth. I was attended to very well. They accompanied me and the baby was born healthy." 20-year-old mother, Matagalpa

\section{Security of health facilities}

Health facility-based care increased women's sense of security and safety, which contributed to their perception of the value of institutional care and encouraged further utilization of ser- vices. Women's perception that facility-based care provides a safe environment for receiving care evolved from the quality of care they received and their delivery outcomes with previous pregnancies. Many women who experienced complications with previous births or low parity had an increased fear and awareness of the risks involved in failing to seek care and thus sought care to avoid complications.

"More than any of the support, the greatest support of all is the support of the hospital because of the safe delivery." 29-year-old mother, Matagalpa

"There are [some] parteras who are prepared [to care for women] in the home, but not all, so sometimes I am afraid. Not all parteras are well prepared." 32-yearold mother, La Dalia

"I decided [to use the services] because-[in case of an] emergency. Because if I needed an IV solution or blood or if the baby was born sick there is also a doctor. Because if someone is born sick then they have to stay there. ... If something occurred in the home it is not as if it were in the hospital." 19-year-old mother, Matagalpa

"When a mother dies it is because she did not attend her prenatal visits at the health centers. With my first son, he died because I started having pains in the home and they took me out of here and sent me to the hospital in [community X]. They told me that the baby was born sick, and three days after he was born, he died in the hospital in [community X].... Yes, I went to all of my visits . . and to deliver, I went 15 days before to the maternity house." 21-year-old mother, Waslala

\section{Communication}

Many women stated that their knowledge of pregnancy and delivery practices came from health workers, prior experience, or other more experienced women in the community, especially their mothers and mothers-inlaw. Open communication with one's husband about the importance of seek- 
ing care also facilitated a woman's utilization of services. It was evident that the women who used the casa materna had received information from health workers or community members regarding the services offered and the purpose of the casa materna. Women who acknowledged their fears of complications and risks related to poor maternal and infant outcomes often communicated their feelings and received encouragement to seek care to avoid complications. A few women reported their desire to begin family planning to minimize the risk of complications due to birth spacing and high parity.

"When one does not know [one] asks the parteras and the people, the older women. Some ask the older women who have had an abundance of children." 29-year-old mother, Matagalpa

"My mother told me that we were going to the hospital because the second [pregnancy] I was very sick, so I went. I tell you that you can be very weak and also the birth can cause you to hemorrhage and you can die." 28-year-old mother, La Dalia

"Every month my husband told me, 'Today go to your [prenatal] visit. You have to go because it is important because you do not want to go to the hospital,' he says, 'but it is important to go to your [prenatal] visits because someone tells you how you are [doing].' He never told me not to go." 28-year-old mother, Matagalpa

"Where we live, a woman works there. She said that a pregnant woman that goes to the casa materna goes to the health center. I went to the casa materna because there it is much faster to get a woman [to the health center] and it does not take much time. Then I went with this son that I have now." 30-year-old mother, La Dalia

\section{Traditional practices}

Many of the women who did not seek prenatal or delivery care stated that they were not accustomed to using prenatal care and were familiar with delivering at home like other women in their families. These women often only experienced minor (if any) complications during labor and delivery. Women's persistent disdain and distrust for health care workers, including parteras, strengthened their desire to rely on familiar, traditional forms of care. While a majority of people in Nicaragua maintain strong religious conviction, women often attributed health careseeking behaviors and both positive and negative outcomes of past experiences to fate. Women's strong fatalistic beliefs were used to justify failure to seek care and reflected a sense of limited control over health outcomes.

"I did not want to go to the hospital because I am used to delivering in the home." 23-year-old mother, Waslala

". . . There was [a partera] but she was old, and I do not like her because she is a Sandinista. Sometimes ... there is [no] partera." 35-year-old mother, Waslala

"Afterward, when the doctor checked on me, I told him that I did not want to go [home] because I still felt bad, but [then] I left because the people [at the hospital] are very bad and because they didn't have time for me the following day." 28-yearold mother, Matagalpa

". . . If you do not have money, you deliver alone. It is the will of God." 22-yearold mother, La Dalia

\section{Previous experiences}

Women's past experiences with poor-quality care or unclear information in health facilities influenced future behaviors. Poor communication or miscommunication with health professionals also contributed to women's misperceptions and lack of understanding regarding healthy behaviors and potential complications, as revealed in the interviews. Reported misdiagnoses or unclear communication from health workers and other women in the community have led to delayed antenatal care visits and home deliveries. Uncomfortable or negative past experiences receiving care-including lack of attendance, excessive waiting times, lack of agency regarding one's health, and embarrassing physical examinations-discouraged women from seeking care at health facilities. A few women who experienced complications and had to deliver via cesarean section believed returning to the health facility for a future delivery would result in the same outcome. Complications that resulted after having received care from a partera have deterred women from seeking future care at facilities or from parteras.

"She had to go, the poor woman, and she spent all day here and left at four in the afternoon from here and arrived at home at eight at night and then said she would not go back because she says that no one attends to you in the [health] center and it is too full and there are not sufficient doctors so it is not easy... . She decided to stay in her house and if she were to die she would be there." 40-year-old mother, La Dalia

"The first months I did not come because when I arrived at five months or four months I began my visits, but the doctor did not attend to me because he did not believe that I was pregnant and I went to [community X] and had an exam and afterward he did my visits [exams]." 25-year-old mother, Matagalpa

"[The health provider] told me, 'I am not going to send you [to the casa materna] because you have a lot of time left. No; go to your house'... . I left from the center at 12 and arrived at [my] house and he was born at three in the morning." 30-year-old mother, La Dalia

"I didn't look for a partera because with the first birth that was attended by the partera they did a cesarean section and because of this I remained scared to trust the partera." 34-year-old mother, La Dalia

\section{Shared information}

Women's decisions to seek care were affected by prevailing rumors of other women's adverse experiences, 
negative perceptions, and shared misconceptions that remained uncorrected by health workers or other formal sources of information. A woman's fear of receiving vaccinations, being touched or examined by health workers, and taking unsafe transportation to reach a health facility prevented some women from attending prenatal visits. Women reported that their fear of delivering in health facilities is related to the shared perceptions that delivering in a health facility causes illness or guarantees a cesarean section delivery.

"It troubles me because many women tell me that they were touching the tummy, they were lifting the dress, and [because of] fear of the vaccinations, because I have been terrified of vaccinations ... since I [started family] planning, because look at my age. I have never been at a boarding [inpatient] hospital." 34-year-old mother, La Dalia

"Not in the hospital, because they give you milk, and milk is bad. They give you fatty ingredients, and fatty ingredients are bad.... Cancerous tumors and vaginal cancers come from the fat." 22-year-old mother, La Dalia

"Sometimes it scares me because they say that the hospital can cause a woman to swell. They tell me this and it scares me so I did not go to the hospital." 40-year-old mother, La Dalia

\section{Gender and power issues}

Women's lack of autonomy and mobility in the study region is illustrated by their need to receive permission from their bosses or partners to seek care. Women working and living in haciendas (farms) or working outside of their own agricultural land or home reported having to receive permission from bosses or managers to seek prenatal care. Women reported that men expressed jealousy if their wives were examined by a health practitioner and, as a result, women were not permitted to seek care or chose not to in order to avoid potential violence or conflict.
"Since I live alone working, out of necessity working in the kitchen, my bosses did not allow me to leave so I went on being pregnant and did not leave until I delivered. . . My bosses were demanding and did not allow me to leave." 28-yearold mother, Waslala

"When the husband tells her that she can not go ... no, no, the woman can not go. Then she has to stay and bear it." 25-year-old mother, Waslala

"Sometimes because they are jealous. ... Jealousy perhaps because of not wanting the doctor to look at her or because he does not want [the doctor] to see her vagina." 25-year-old mother, Waslala

"When men hit us it is when we are with another man, right. Thus, we have to respect them and keep only one husband, because there are husbands that do not like when their wives speak to other men because there are husbands that get jealous, right. They may think 'my woman is betraying me'; [when] he hits me [I] think that he is imagining things." 22-year-old mother, La Dalia

Women were discouraged from accessing services because they feared straying from their role as the caretaker by leaving their children, animals, and homes unattended in order to commit a substantial amount of time to seeking care. Community expectations of a mother to act as the caregiver were reinforced by the husband's demand for her to remain at home. As a result of society's acceptance of the husbands' dominant role within the family, many women attributed poor maternal outcomes to the husbands' control over women's health care utilization. Women also mentioned that the degree of support a man provides throughout a woman's pregnancy and delivery may vary depending on whether or not the new baby is his own biological child.

"I did not leave because I felt sorry to leave the other children alone." 22-yearold mother, Waslala

"Sometimes she dies because the husband does not allow her to go to her prena- tal visits.... The husbands do not allow them to go. They say to them that they have to care for the other [children in the household]." 25-year-old mother, Waslala

"There are women whose men left them who have to go to work with this big belly. ... In my community a woman died... she was out working in the coffee fields but she had a man. But what happened was that he was not the father of her child she was about to have and during the entire pregnancy she was in the coffee fields and the child was born dead because she often wore a corset and she ignored her tummy when lifting the baskets." 21-yearold mother, La Dalia

\section{DISCUSSION}

This study examined the logistical and perceived barriers women confront when accessing maternal health services within the cultural context of Matagalpa, Nicaragua. The study has identified a range of logistical barriers to seeking care that have also been shown to be important in other countries and cultural contexts $(9,11,16$, 20). The findings indicate that financial obstacles, especially in relation to transportation, time constraints, and availability of health care staff and services influence women's utilization of prenatal and delivery services. While previous studies in Matagalpa have addressed logistical barriers, specifically at the health facility level, no study has previously addressed the underlying social and cultural perceptions influencing women's utilization of services in this region (34).

Women who perceive prenatal and delivery care to be relevant overcome the logistical barriers with the support of family members, most notably their husbands and mothers or mothersin-law. Various factors facilitate women's utilization of institutional-based maternal health services, including establishing financial savings, most often with the support of their husbands; timely preparation for delivery, including staying at the casa materna; and arranging for a family member or friend to accompany them, or to care 
for their other children. However, women's utilization of prenatal care does not necessarily translate to use of institutional delivery care. While it appears that parity may affect a woman's use of delivery services, the themes identified in the study did not clearly vary by women's age or parity. It is possible that low-parity women face fewer opportunity costs in relation to caring for additional children when seeking delivery services. Some women's intentions to seek delivery care may be thwarted by their failure to access or pay for emergency transportation or their inability to travel due to extremely rapid labor. However, these barriers do not completely explain the discrepancy between the use of prenatal services and the use of delivery services. The data show that a range of sociocultural factors may explain this disconnect between women's utilization of prenatal and delivery services.

Logistical barriers, which are a product of the political and economic environment, are easier to surmount than the intergenerational cultural influences in this region. Women's utilization of services is affected by the varying degree to which they receive information about health care through formal and informal sources, including other women in the community, health workers, and partners. Furthermore, the level of encouragement and promotion of healthy maternal health care-seeking behaviors provided by those information resources influences a woman's ability to overcome the cultural barriers to seeking care.

In the study setting, cohesive women's networks within families and communities link women and disseminate their knowledge and experiences. The data reveal that women's disclosure of past experiences, traditional practices, and prevailing fears and misconceptions influence their attitudes toward prenatal and delivery care as well as their utilization of services. Women often rely on the knowledge and advice of older, more experienced authority figures within their network to direct their health careseeking behaviors. Women's perceptions of prenatal and delivery care is enhanced through positive personal experiences; an established sense of security in health facilities; shared positive experiences; and direct, comprehensive communication with health workers. The disconnect between utilization of prenatal care and delivery services may be attributed to women's collective comfort with receiving prenatal care at well-known rural health clinics versus their apprehension at receiving delivery services at the larger and better equipped yet unfamiliar health centers.

Women's utilization of prenatal and delivery services is influenced by communal and individual perceptions regarding maternal care. This study reveals the shared cultural belief that a woman's role is to be the caretaker of her children. Women's acceptance of their prescribed gender role as the passive caretaker of the family heightens the perceived opportunity costs of seeking care. For women, prenatal care is considered necessary primarily to ensure the health of a child rather than to protect one's own health. There is a disconnect in how women view prenatal and delivery care in relation to the health and security of their child, which may result in the difference in their utilization of antenatal and delivery services. Further research is warranted to examine the external and internal construction of this caretaker role and the degree to which it extends to the unborn child. Better understanding of how the expectations of other women, and husbands, influence women's perceptions of their duties as a caretaker may shed light on women's use of institutional delivery services and its influence on neonatal survival and overall child health.

Nicaragua is a country in which machismo is manifested within the political, social, and cultural environment and may be exhibited in the behaviors of individual men (33). According to Sternberg (33), machismo is a dominant, dynamic component of a value system that justifies the subordination of women and governs the relationships among men in which women are considered "a form of currency." Women's acceptance of an idealized notion of motherhood and serving the family leaves them economically dependent on men. This dependence grants men the authority, both in the workplace and in the home, to dictate women's mobility and autonomy in accessing maternal health care services. A husband's perception of the relevance of accessing maternal health services is an important factor influencing a woman's health care-seeking behavior. While a previous study in Nicaragua revealed that men believe they have the right to decide when a woman should have children, further research regarding husbands' perceptions and interpersonal communication regarding maternal health care is necessary for understanding women's health care-seeking behaviors (33).

The study results should be considered within the scope of the limitations. Interviews were only conducted with mothers seeking care for their child at a health clinic, thus the results are not necessarily representative of women who never seek care at health facilities. An additional limitation of this study is the effect of a threemonth-long health workers' strike five months prior to beginning the research on prenatal and delivery care practices. In addition, as with all research involving self-reported interview responses, there was a potential for recall bias, particularly in reporting number of prenatal visits. Furthermore, women who were accompanied by their husbands to the health facilities on the days of the interviews may have been hesitant to disclose details about their relationships with their husbands. As a result, gender power dynamics at the household level, which may not have been completely understood, may have affected the study outcome.

\section{CONCLUSION}

This study highlights the logistical and sociocultural barriers impeding women's utilization of maternal health services in Matagalpa, Nicaragua. Enhanced health care infrastructure and human resource capacity would improve overall access to services and 
would likely increase service utilization. As demonstrated in this study, better understanding of community and individual perceptions about prenatal care, the quality of services, and women's health needs may improve the efficacy of public health interventions and contribute to increased utilization and effectiveness of maternal health services. Women's ability to convene and communicate is a powerful force that-if better understood by researchers-could be used as a tool for public health interventions. Future public health research should therefore target women's networks and the information being communicated via those interpersonal relationships.

Investigating women's concerns regarding quality of care and lack of communication between health workers and patients may improve services and increase consumer confidence. The high level of utilization of prenatal care services provides an opportunity to improve the content and effectiveness of prenatal care while encouraging healthy maternal care practices, including delivering in health facilities. Incorporating prenatal and delivery education and counseling into standard prenatal visits will allow health workers to address women's questions and misconceptions regarding care and delivery. Discussions about pregnancy and postpartum danger signs, adequate nutrition during pregnancy, delivery care services, casa materna utilization, and postpartum care could inform women about appropriate care and the types of services available while initiating a dialogue about concerns women may have regarding these issues. Alleviating misconceptions and fears and reducing the gap in maternal health knowledge during prenatal care may contribute to an increase in the utilization of delivery services. Communication with women about their expectations and perceptions of health facility deliveries, along with other issues, could improve community awareness of the importance of delivery services in regard to the health of their unborn children. Prenatal care visits should also be used to educate women on how to avoid logistical barriers at the time of delivery. Human resources at rural health facilities, which are often understaffed, could be supplemented by trained local community health workers to reduce the workload of physicians or nurses, introduce effective education and counseling, and encourage repeat use of services.

This study highlights how men's financial power and women's acceptance of their passive gender role limits women's agency in their own health care. To maximize community understanding and acceptance of maternal health services, public health interventions must target men, who often control women's health-seeking practices. As the inclusion of men in maternal health programs has proven controversial, more research and comprehensive monitoring and evaluation of programs involving men are needed to ascertain the male influence on women's utilization of maternal health services.

Acknowledgements. Funding for this research was provided through The O. C. Hubert Charitable Trust and the Global Field Experiences Program at the Rollins School of Public Health, Emory University. The authors wish to thank CARE and Annie Rivera, Mercedes Eritzia, and Erlinda Ruiz from Nicaragua for their support in conducting this research. The authors are grateful to the many Nicaraguan women who candidly shared their personal experiences.

\section{REFERENCES}

1. AbouZahr C, Wardlaw T. Maternal mortality in 2000: estimates developed by WHO, UNICEF and UNFPA. Geneva: World Health Organization; 2004.

2. AbouZahr, C. Global burden of maternal death and disability. Br Med Bull. 2003;67(1): $1-11$

3. Acosta AA, Cabezas E, Chaparro JC. Present and future of maternal mortality in Latin America. Int J Gynecol Obstet. 2000;70(1): 125-31.

4. Pan American Health Organization; UNICEF. Salud materna e infantil en Nicaragua: avances y desafíos 2005. MINSA, Estrategia para la implementación y seguimiento de los Cuidados Obstétricos Esenciales (COE). Managua: COE; 2004.

5. Guerra G. Beating women is a way of life here. JANE Magazine [magazine article on the Internet]. 2001 Feb. Available from: http:// www.unfpa.org/focus/nicaragua/ms magazine.htm. Accessed 18 January 2007.

6. Thaddeus S, Maine D. Too far to walk: maternal mortality in context. Soc Sci Med. 1994; 38(8):1091-110.
7. Berg C, Danel I, Zane S, Bartlett L, eds. Strategies to reduce pregnancy-related deaths: from identification and review to action. Atlanta, Centers for Disease Control and Prevention; 2001. p. 45-7. In: Bullough C, Meda N, Makowiecka K, Ronsmans C, Achadi E, Hussein J. Current strategies for the reduction of maternal mortality. BJOG. 2005;112(9):1180-8.

8. Wagstaff A. Poverty and health sector inequalities. Bull World Health Organ. 2002; 80(2):97-105. In: Osubor K, Fatusi A, Chiwuzie J. Maternal health-seeking behavior and associated factors in a rural Nigerian community. Matern Child Health J. 2006; 10(2):159-69.

9. Onah H, Ikeako L, Iloabachie G. Factors associated with the use of maternity services in Enugu, Southeastern Nigeria. Soc Sci Med. 2006;63(7):1870-8.

10. Ram F, Singh A. Is antenatal care effective in improving maternal health in rural Uttar Pradesh? Evidence from a district level household survey. J Biosoc Sci. 2006;38(4): $433-48$.
11. Griffiths P, Stephenson R. Understanding users' perspectives of barriers to maternal health care use in Maharashtra, India. J Biosoc Sci. 2001;33(3):339-59.

12. Nicaragua, Ministerio de Salud. Boletines epidemiológicos año 2006. Tablas Epidemiológicas [tables on the Internet]. Managua: Ministerio de Salud; 2007. Available from: http:// www.minsa.gob.ni/vigepi/html/arc2006. html. Accessed 2 February 2007.

13. United Nations Development Programme. Negro futuro para mujeres en 2007. La Prensa [newspaper article on the Internet]. $2006 \mathrm{Dec}$ 18. Available from: http://www.undp.org. $\mathrm{ni} /$ noticia.php?idnoticia $=307$. Accessed 20 January 2007.

14. Population Reference Bureau. Women of our world 2005 [document on the Internet]. Washington, D.C.: PRB; 2005. Available from: www.prb.org/pdf05/WomenOfOurWorld 2005.pdf. Accessed 12 February 2007.

15. Nicaragua, Instituto Nacional de Estadísticas y Censos. Macro International Inc. Encuesta Nicaragüense de demografía y salud 2001. 
Calverton (MD): ORC Macro/DHS+ Program; 2002.

16. Osubor K, Fatusi A, Chiwuzie J. Maternal health-seeking behavior and associated factors in a rural Nigerian community. Matern Child Health J. 2006;10(2):159-69.

17. Mikhail B. Perceived impediments to prenatal care among low-income women. West J Nurs Res. 1999;21(3):335-55.

18. Beckmann C, Buford T, Witt J. Perceived barriers to prenatal care services. The Am J Matern Child Nurs. 2000;25(1):43-6.

19. Stephenson R, Tsui AO. Contextual influences on reproductive health service use in Uttar Pradesh, India. Stud Fam Plann. 2002;33(4): 309-20.

20. Islam M, Nielsen C. Maternal and child health services: evaluating mothers' perceptions and participation. Public Health. 1993;107(4): 243-9.

21. Myer L, Harrison A. Why do women seek antenatal care late? Perspectives from rural South Africa. J Midwifery Women's Health. 2003;48(4):268-72.

22. Larsen G, Lupiwa S, Kave H, Gillieatt S, Alpers M. Antenatal care in Goroka: issues and perceptions. P N G Med J. 2004;47(3-4): 202-14.
23. Abrahams N, Jewkes R, Mvo Z. Health careseeking practices of pregnant women and the role of the midwife in Cape Town, South Africa. J Midwifery Women's Health. 2001; 46(4):240-7.

24. Castro R, Campero L, Hernández B, Langer A. A study on maternal mortality in Mexico through a qualitative approach. J Women's Health \& Gender-Based Med. 2000;9(6):679-90.

25. Chapman RR. Endangering safe motherhood in Mozambique: prenatal care as pregnancy risk. Soc Sci Med. 2003;57(2):355-74.

26. Nwakoby BN. Use of obstetric services in rural Nigeria. J Roy Soc Health. 1994;114(3): 132-6. In: Onah H, Ikeako L, Iloabachie G. Factors associated with the use of maternity services in Enugu, southeastern Nigeria. Soc Sci Med. 2006;63(7):1870-8.

27. Camacho A, Castro M, Kaufman R. Cultural aspects related to the health of Andean women in Latin America: a key issue for progress toward the attainment of the Millennium Development Goals. Int J Gynecol Obstet. 2006;94(3):357-63.

28. Coverston C, Franklin C, Patterson Davis J. Seeking safe passage: Argentine women's perceptions of routine prenatal care. Health Care Women Int. 2004;25(7):620-35.
29. Shen C, Williamson J. Maternal mortality, women's status, and economic dependency in less developed countries: a cross-national analysis. Soc Sci Med. 1999;4(2)9:197-214.

30. Okafor C, Rizzuto R. Women's and healthcare providers' views of maternal practices and services in rural Nigeria. Stud Fam Plann. 1994;25(6):353-61.

31. Sai F, Measham D. Safe Motherhood Initiative: getting our priorities straight. Lancet. 1992;339(8791):478-80.

32. Merrill T, ed. Nicaragua: a country study. Washington, D.C.: Federal Research Division, Library of Congress; 1994.

33. Sternberg P. Challenging machismo: promoting sexual and reproductive health with Nicaraguan men. Gend Dev. 2000;8(1):89-99.

34. Benagiano G, Thomas B. Safe Motherhood: the FIGO initiative. Int J Gynecol Obstet. 2003; 82(3):263-74.

Manuscript received on 1 August 2007. Revised version accepted for publication on 18 March 2008.
RESUMEN

\section{Utilización de los servicios de salud materna en el departamento de Matagalpa, Nicaragua}

\section{Palabras clave}

Objetivos. Mejorar el conocimiento sobre las percepciones y los factores personales y comunitarios que influyen en la búsqueda de atención médica durante el embarazo, con vistas a aumentar la utilización de los servicios de salud materna.

Métodos. Mediante 37 entrevistas semiestructuradas en profundidad aplicadas a mujeres del departamento de Matagalpa, Nicaragua, se investigaron las barreras logísticas y socioculturales que influyen en la utilización de los servicios de salud materna.

Resultados. Los resultados muestran que sobre la demora en la búsqueda de atención sanitaria durante el embarazo influyeron no solo el escaso acceso y las barreas económicas, sino también el conocimiento individual y comunitario sobre los servicios de salud materna y su grado de aceptación. El apoyo de la pareja, el haber recibido atención médica durante embarazos previos y el grado de comunicación con otras mujeres y trabajadores sanitarios influyeron en la decisión de las embarazadas de buscar atención.

Conclusiones. Los datos indican que para mejorar la salud materna en esta región, las intervenciones se deben dirigir a diversos niveles: el individuo, el hogar y la comunidad.

Mortalidad materna, servicios de salud materna, Nicaragua. 